\title{
Rescue of Neurons from Ischemic Injury by Peroxisome Proliferator-Activated Receptor- $\gamma$ Requires a Novel Essential Cofactor LMO4
}

\author{
Sarah C. Schock, ${ }^{1 \star}$ Jin Xu, ${ }^{1 *}$ Philippe M. Duquette, ${ }^{1}$ Zhaohong Qin, ${ }^{1}$ Adam J. Lewandowski, ${ }^{1}$ Punarpreet S. Rai, ${ }^{1}$ \\ Charlie S. Thompson, ${ }^{1}$ Erin L. Seifert, ${ }^{2}$ Mary-Ellen Harper, ${ }^{2}$ and Hsiao-Huei Chen ${ }^{1,3}$ \\ ${ }^{1}$ Ottawa Health Research Institute, Neuroscience, ${ }^{2}$ Department of Biochemistry, Microbiology and Immunology, and ${ }^{3}$ Department of Medicine, University \\ of Ottawa, Ottawa, Ontario, Canada K1H 8M5
}

\begin{abstract}
Activation of peroxisome proliferator-activated receptor- $\gamma(\operatorname{PPAR} \gamma)$ signaling after stroke may reduce brain injury, but this effect will depend on the levels of receptor and cofactors. Here, we showed that the direct effect of PPAR $\gamma$ signaling to protect neurons from ischemic injury requires a novel cofactor LMO4, because this effect was lost in LMO4-null cortical neurons. PPAR $\gamma$ agonist also failed to reduce cerebral infarction after transient focal ischemia in CaMKII $\alpha$ Cre/LMO4loxP mice with LMO4 ablated in neurons of the forebrain. Expressing LMO4 in LM04-null cortical neurons rescued the PPAR $\gamma$-protective effect. PPAR $\gamma$ signaling activates the promoter of the antioxidant gene SOD2 and this process requires LMO4. Addition of a superoxide dismutase mimetic MnTBAP [manganese(III)tetrakis(4-benzoic acid)porphyrin] bypassed the deficiency in PPAR $\gamma$ signaling and was able to directly rescue LMO4null cortical neurons from ischemic injury. Like LM04, PPAR $\gamma$ and $\operatorname{PGC1} \alpha(\operatorname{PPAR} \gamma$ coactivator $1 \alpha)$ levels in neurons are elevated by hypoxic stress, and absence of LMO4 impairs their upregulation. Coimmunoprecipitation and mammalian two-hybrid assays revealed that LMO4 interacts in a ligand-dependent manner with PPAR $\gamma$. LMO4 augments PPAR $\gamma$-dependent gene activation, in part, by promoting $\operatorname{RXR} \alpha$ (retinoid X receptor- $\alpha$ ) binding to PPAR $\gamma$ and by increasing PPAR $\gamma$ binding to its target DNA sequence. Together, our results identify LMO4 as an essential hypoxia-inducible cofactor required for $\operatorname{PPAR} \gamma$ signaling in neurons. Thus, upregulation of LMO4 expression after stroke is likely to be an important determinant of neuron survival.
\end{abstract}

Key words: LM04; PPAR $\gamma$; stroke; excitotoxicity; hypoxia; SOD2

\section{Introduction}

Diabetes mellitus is a major risk factor for stroke. The nuclear receptor peroxisome proliferator-activated receptor- $\gamma(\operatorname{PPAR} \gamma)$ plays a key role in the regulation of glucose and lipid metabolism (Boyle, 2007) and synthetic ligands of PPAR $\gamma$ are used to treat insulin-resistant diabetes. In diabetic patients who had a previous stroke, the PPAR $\gamma$ agonist pioglitazone reduced by almost onehalf the incidence of a second stroke (Wilcox et al., 2007). Moreover, higher levels of endogenous PPAR $\gamma$ ligand 15-deoxy$\Delta 12,14$-prostaglandin J2 (PGJ2) are correlated with a smaller infarction in patients with atherothrombotic stroke (Blanco et al., 2005). In experimental models of stroke, PPAR $\gamma$ agonists protect the brain from ischemic injury and reduce infarction if adminis-

\footnotetext{
Received June 24, 2008; revised Sept. 18, 2008; accepted 0ct. 8, 2008.

This work was supported by grants from Canadian Foundation for Innovation, Ontario Research Fund, Canadian Institutes for Health Research, Heart and Stroke Foundation of Canada, and Centre for Stroke Recovery of Heart and Stroke Foundation of Ontario (H.-H.C.). We thank Drs. Ghosh, Abe, and Yang for the expression plasmids and Drs. Rabbitts, Visvader, Schütz, and Ruth Slack for transgenic mice. We thank Dr. Sheng Hou for training and consultation on the MCAO procedure and Drs. Chris Kennedy and Alexandre Stewart for the assistance of measuring physiological parameters. We are grateful for Dr. Stewart for helpful discussion and reading this manuscript.

*S.C.S. and J.X. contributed equally to this work.

Correspondence should be addressed to Hsiao-Huei Chen, Ottawa Health Research Institute, Neuroscience, 451 Smyth Road, Room 2422, Ottawa, Ontario, Canada K1H 8M5. E-mail: hchen@uottawa.ca.

D01:10.1523/JNEUROSCI.2897-08.2008

Copyright $\odot 2008$ Society for Neuroscience $\quad$ 0270-6474/08/2812433-12\$15.00/0
}

tered within $2 \mathrm{~h}$ after middle cerebral artery occlusion (MCAO) in part by an antiinflammatory effect that reduces cytokine production from microglia (Luo et al., 2006). In addition, PPAR $\gamma$ agonists have a direct effect on neurons and increase their survival of NMDA-induced excitotoxicity (Uryu et al., 2002; Zhao et al., 2006). High levels of PPAR $\gamma$ are detected in the brain of mouse embryos, and PPAR $\gamma$ plays a critical role during embryonic neurogenesis, controlling neural stem cell proliferation (Wada et al., 2006). PPAR $\gamma$ expression is upregulated in adult cortical neurons in response to ischemic injury (Victor et al., 2006; Zhang et al., 2008), suggesting that the activation of PPAR $\gamma$ signaling may be a natural defensive mechanism.

The ability of PPAR $\gamma$ signaling to protect neurons depends on the levels of PPAR $\gamma$ expression, the presence of ligand, and also the availability of cofactors including PGC- $1 \alpha$ (PPAR $\gamma$ coactivator- $1 \alpha$ ) (Puigserver et al., 1998), the histone acetyltransferase CBP (CREBbinding protein)/p300, and the hydrogen peroxide-inducible clone-5 (Hic5) (Drori et al., 2005). Hic5 contains four Lin-11/Isl-1/ Mec-3 (LIM) domains, zinc finger protein/protein interaction domains that interact with $\operatorname{PPAR} \gamma$. Hic5 is required for PPAR $\gamma$ dependent differentiation of colon epithelium (Drori et al., 2005). However, very low levels of Hic5 are detected in the brain (Shibanuma et al., 1994; Jia et al., 2001), and it is unclear whether Hic5 is required for PPAR $\gamma$-dependent neuroprotection. 
However, the small nuclear LIM domain-only protein LMO4 is highly expressed in the developing nervous system (Hermanson et al., 1999; Chen et al., 2002) and in primary cultured neurons but not in glia (Chen et al., 2007b). We found that expression of LMO4 is tightly regulated. LMO4 mRNA and protein levels increase in cultured cortical neurons exposed to elevated extracellular ATP, conditions that are prevalent after ischemia in the brain (Chen et al., 2007a,b). Moreover, we showed that LMO4 promotes cortical neuron survival from chemically induced hypoxia (Chen et al., 2007b). Here, we showed that LMO4 interacts with PPAR $\gamma$ and mediates PPAR $\gamma$ signaling in neurons. Because mice that lack LMO4 die at birth, with defects in neural tube closure (Hahm et al., 2004; Tse et al., 2004; Lee et al., 2005), we generated mice with neuron-specific postnatal deletion of LMO 4 in the forebrain (CaMKII $\alpha$ Cre/LMO4loxP mice) to address the function of LMO4 in adult mice. Although morphological and physiological parameters appear normal, we found that CaMKII $\alpha$ Cre/LMO4loxP mice are highly susceptible to focal cerebral ischemia, and that PPAR $\gamma$ agonist failed to limit ischemic injury in these mice. Our study is the first to identify LMO4 as an essential cofactor required for PPAR $\gamma$-dependent neuron protection from ischemic injury in vivo.

\section{Materials and Methods}

Reagents. Except for manganese(III)tetrakis(4-benzoic acid)porphyrin (MnTBAP) (Calbiochem), rosiglitazone, 2-chloro-5-nitrobenzanilide (GW9662), NMDA, KCN, 2,3,5-triphenyltetrazolium chloride monohydrate (TTC), 4',6-diamidino-2-phenylindole dihydrochloride (DAPI) were purchased from Sigma-Aldrich.

Antibodies. Commercial monoclonal antibodies to Flag and actin (Sigma-Aldrich) and NeuN (Invitrogen), rabbit polyclonal to PPAR $\gamma$, PGC1 $\alpha$, and superoxide dismutase 2 (SOD2) (Santa Cruz), rabbit polyclonal to Cre recombinase (Abcam), and goat polyclonal to hsp60 and to LMO4 (Santa Cruz) were used. Custom-made rabbit peptide-specific antibody to LMO4 was described previously (Chen et al., 2007a).

Plasmids and expression constructs. Expression vectors for Hic5 (Drori et al., 2005), Flag-tagged PPAR $\gamma 2$ (Puigserver et al., 1998), retinoid X receptor- $\alpha(\operatorname{RXR} \alpha)$ (Tontonoz et al., 1994), and a luciferase promoter reporter construct containing three DR1 consensus $\operatorname{PPAR} \gamma$-responsive elements (PPRE X3-TK-luc) (Puigserver et al., 1998) were purchased from Addgene, and Sport6LMO4 was from Open Biosystems. Myctagged LMO4 wild-type, C23S, and C87S expression vectors were from Anirvan Ghosh (University of California, San Diego, La Jolla, CA). Gal4PPAR $\gamma 1$ mammalian two-hybrid constructs were from Jun-Ichi Abe (University of Rochester, Rochester, NY). Gal4-PPAR $\gamma 2$ constructs containing amino acids $183-505$ or 318-505 were generated by PCR from wild-type or E499Q mutant PPAR 2 (Puigserver et al., 1998). The fulllength RXR $\alpha$ sequence was obtained by PCR and fused to the activation domain of VP16 in the pACT vector (Promega). The ActLMO4(WT), ActLMO4(C23S), and ActLMO4(C87S) were amplified by PCR from expression vectors and cloned into the pAct vector. Gal4 and Act fusion protein expression vectors were cotransfected with a Gal4-responsive luciferase reporter (Clontech) and the level of luciferase activity was used as a readout of protein interaction. Luciferase reporter constructs containing the promoter sequences of SOD2-985 to +195 and -935 to +195 (Ding et al., 2007) were from Qinglin Yang (Morehouse School of Medicine, Atlanta, GA). A bicistronic CMV-LMO4/IRES-GFP expression construct containing mouse LMO4 was generated by PCR. All constructs were verified by sequencing.

F11 cells or primary cortical neurons were transiently transfected as described previously (Chen et al., 2007b). In brief, cells were transfected with $400 \mathrm{ng}$ of luciferase-expressing vector and $100 \mathrm{ng}$ of indicated expression constructs or appropriate empty vectors (e.g., cDNA3) and 200 ng of pCMV $\beta$ gal to normalize transfection efficiency per well of 12-well plate. Transfection was performed with a 1.5 ratio of total plasmid/Lipofectamine 2000 reagent (Invitrogen). Ten micromolar rosiglitazone or vehicle was applied to the culture medium the day after transfection for
$8 \mathrm{~h}$. Cells were harvested $16-24 \mathrm{~h}$ after transfection, and Luciferase and $\beta$-galactosidase assays were performed (Ou et al., 2000). For all experiments, assays were done in triplicate and repeated three times or as indicated. Luciferase activities were compared by paired $t$ test and considered significant at the $p<0.05$ level.

Primary neuronal cultures, ischemic insults, and cell survival assay. Primary cultures of cortical neurons were prepared from LMO4-null [knock-out (KO)] or littermate wild-type control (WT) 14.5-d-old mouse embryos as we described previously and maintained for 12-14 d in vitro (Chen et al., 2007b). For oxygen and glucose deprivation (OGD)/ reperfusion, cultures were washed twice with a balanced salt solution at room temperature with the following composition: $140 \mathrm{~mm} \mathrm{NaCl}, 3.5$ mм KCl, $0.4 \mathrm{~mm} \mathrm{KH}_{2} \mathrm{PO}_{4}, 5 \mathrm{~mm} \mathrm{NaHCO}_{3}, 1.3 \mathrm{~mm} \mathrm{CaCl}_{2}, 1.2 \mathrm{~mm} \mathrm{MgSO}_{4}$, and $10 \mathrm{~mm}$ HEPES, $\mathrm{pH}$ 7.4. Cultures were subjected to an anaerobic environment of $95 \% \mathrm{~N}_{2} / 5 \% \mathrm{CO}_{2}$ for $6 \mathrm{~h}$, returning the stored medium to the cells with or without $10 \mu \mathrm{M}$ rosiglitazone or MnTBAP, and maintained at normal atmospheric $\mathrm{O}_{2}$ with $5 \% \mathrm{CO}_{2}$, at $37^{\circ} \mathrm{C}$. Chemical hypoxia was induced by $1 \mathrm{~mm} \mathrm{KCN}$ for $3 \mathrm{~h}$. Excitotoxicity was induced with $100 \mu \mathrm{M}$ NMDA for 3 or $4 \mathrm{~h}$ as indicated.

Cell survival at day 1 was measured $12-16 \mathrm{~h}$ after treatments by the lactate dehydrogenase (LDH) assay, as described previously (Chen et al., 2007b). For MnTBAP treatment, cell survival at day 2 and day 3 was also measured by the LDH assay, and one-way ANOVA was used to compare the time-dependent cell survival and $p<0.05$ was considered significant. All experiments were performed in quadruplicate and reported as mean \pm SEM

To restore LMO4 expression in cultured cortical neurons derived from LMO4-null embryos, $0.4 \mu \mathrm{g}$ of LMO4-IRES-GFP or control IRES-GFP expression vector together with $1 \mu \mathrm{l}$ of Lipofectamine 2000 (Invitrogen) were transiently transfected to cortical neurons (days in vitro, $2 \mathrm{~d}$ ) cultured on poly-D-lysine-coated coverslips using eight-chamber FLEXIPERM Disc (Greiner Bio-One) for $4 \mathrm{~h}$ with $150 \mu \mathrm{l}$ of Neural Basal medium. Then, $100 \mu \mathrm{l}$ of N2- and B27-supplemented complete medium was added for overnight culture followed by KCN/Rosi treatment or OGD/reperfusion/Rosi treatment the next day. Neurons were fixed with paraformaldehyde, immunostained with LMO4 antibody (C15; Santa Cruz) and nuclei were stained with DAPI. Cells were imaged using a Zeiss M1 microscope with Apotome using the AxioVision software (Zeiss). Cell death was determined by counting cells with condensed or fragmented nuclei in four to seven fields (100-200 cells) per chamber in a blinded manner (Raoul et al., 2002). Data were expressed as the percentage of apoptotic cells among the total $\mathrm{GFP}^{+}$cells counted. Paired $t$ test was used to compare percentage of live transfected neurons, and $p<0.05$ was considered significant.

MitoSOX Red mitochondrial superoxide indicator. Embryonic cortical neurons ( $11 \mathrm{~d}$ in vitro) were subjected $2.5 \mathrm{~h}$ of OGD and reperfused in the presence or absence of $10 \mu \mathrm{M}$ MnTBAP. To monitor superoxide production, MitoSOX (Invitrogen) was added to a final concentration of $0.2 \mu \mathrm{M}$ according to the manufacturer's instructions. Cells were allowed to load MitoSOX for $10 \mathrm{~min}$ and then washed two times with HBSS containing calcium and magnesium and imaged with a Zeiss AxioImager $\mathrm{Z} 1$ with ApoTome fluorescence microscope.

Western blot and immunoprecipitation. Whole-cell protein extracts of cultured F11 cells or cortical neurons were harvested and prepared for Western blot analysis as described previously (Chen et al., 2007a,b). Nuclear fractions of protein extracts of brain samples were prepared as described previously (Solaroglu et al., 2006). Immunoblots were scanned and quantified using the ImageQuant TL software (GE Healthcare). Protein levels of genes indicated were compared by normalizing to $\beta$-actin. Immunoprecipitation was performed using whole-cell extracts prepared from transiently transfected F11 neuronal cells with protein A/G Sepharose (GE Healthcare), as described by the manufacturer. For immunoprecipitation, mouse anti-Flag antibody or LMO4 peptide-specific rabbit antibody (Chen et al., 2007a) was used.

Electrophoretic mobility shift assay. Electrophoretic mobility shift assay (EMSA) was conducted as described previously (Chen et al., 2004, 2007a) using nuclear extract prepared from transfected F11 cells and doublestranded oligonucleotide containing a PPAR $\gamma$ consensus DR1 binding site (underlined): 5'-GGAACTAGGTCAAAGGTCATCCCCT-3' . Anti- 

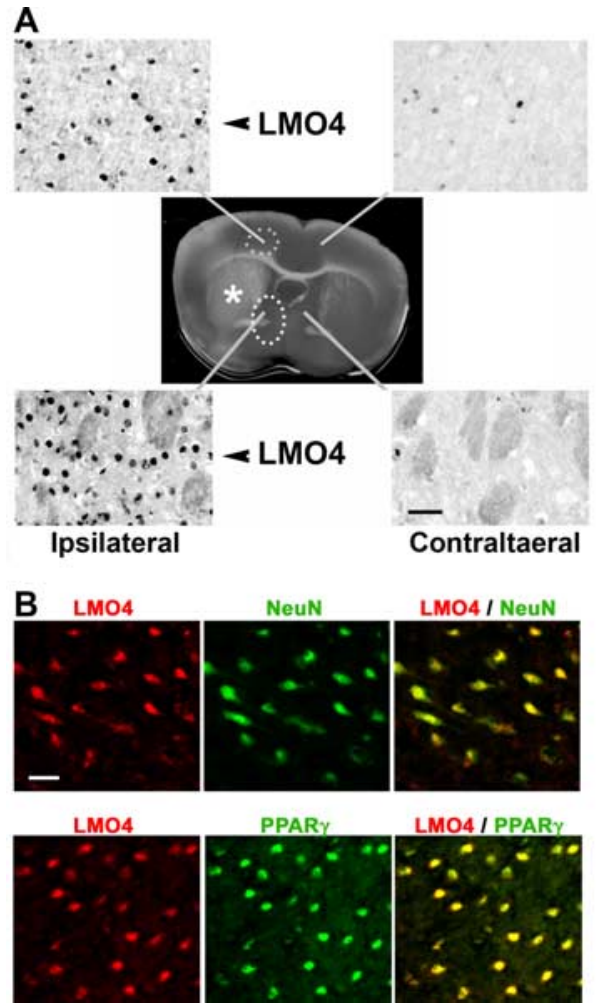

Figure 1. LMO4 levels are increased after ischemic insult. $\boldsymbol{A}$, Immunohistochemistry revealed elevated LMO4 nuclear staining $4 \mathrm{~h}$ after MCAO in the cortex (top two panels) and striatum (bottom two panels) ipsilateral to the infarction (asterisk, white area of TTC staining) compared with the contralateral side. The TTC-stained section from a separate animal is used for illustrative purposes. $\boldsymbol{B}$, LMO4 is upregulated together with PPAR $\gamma$ in the periinfarct area after MCAO. Immunofluorescence staining revealed LMO4 (red) nuclear staining in NeuN-positive (green) neurons. Dual LM04/NeuN staining appears yellow. PPAR $\gamma$ (green) is upregulated in LM04-positive (red) neurons, and dual-stained LM04/PPAR $\gamma$ neurons appear yellow in the periinfarct area of the ipsilateral side. No staining above background was detected for PPAR $\gamma$ or LM04 in the contralateral side (data not shown). Scale bar, $20 \mu \mathrm{m}$. Shown are representative results of $n=3$ mice.

bodies to PPAR $\gamma$ and LMO4 (rabbit peptide-specific) (Chen et al., 2007a) were used in supershift assays. For EMSA using brain nuclear extracts, postnatal day 11 (P11) mice were killed $2 \mathrm{~h}$ after intraperitoneal injection of vehicle or rosiglitazone $(6 \mathrm{mg} / \mathrm{kg})$, and their brains were rapidly removed, dissected, and frozen in liquid nitrogen. Nuclear proteins were extracted from brain tissues as described previously (Luo et al., 2006).

LMO4-null (KO) and CaMKIIaCre/LMO4loxP mice. LMO4 hemizygous mice were obtained from Terrence Rabbitts (MRC Laboratory of Molecular Biology, Cambridge, UK) and genotyped as described previously (Tse et al., 2004). LMO4 homozygous null (KO) and littermate WT embryos were used for primary cultures of cortical neurons.

CaMKII $\alpha$ Cre/LMO4loxP mice with forebrain/neuron-specific ablation of LMO4 were generated by breeding homozygous LMO4loxP mice (Hahm et al., 2004) (gift from Jane Visvader, The Walter and Eliza Hall Institute of Medical Research, Parkville, Victoria, Australia) with heterozygote CaMKII $\alpha$ Cre transgenic mice (Casanova et al., 2001) (gift from Günther Schütz, German Cancer Research Center, Heidelberg, Germany) to obtain CaMKII $\alpha$ Cre mice hemizygous for the LMO4loxP allele. These mice were then backcrossed to the homozygous LMO4loxP mice to obtain CaMKII $\alpha$ Cre/LMO4loxP mice. The neuron-specific CaMKII $\alpha$ promoter is activated in the forebrain (including cortex, striatum, hippocampus) 1 week after birth (Casanova et al., 2001). CaMKII $\alpha$ Cre/LMO4loxP mice and littermate control LMO4loxP mice were genotyped by PCR and used for in vivo MCAO studies. Immunofluorescence staining using antibody to bacteriophage P1 Cre (Novagen)
A
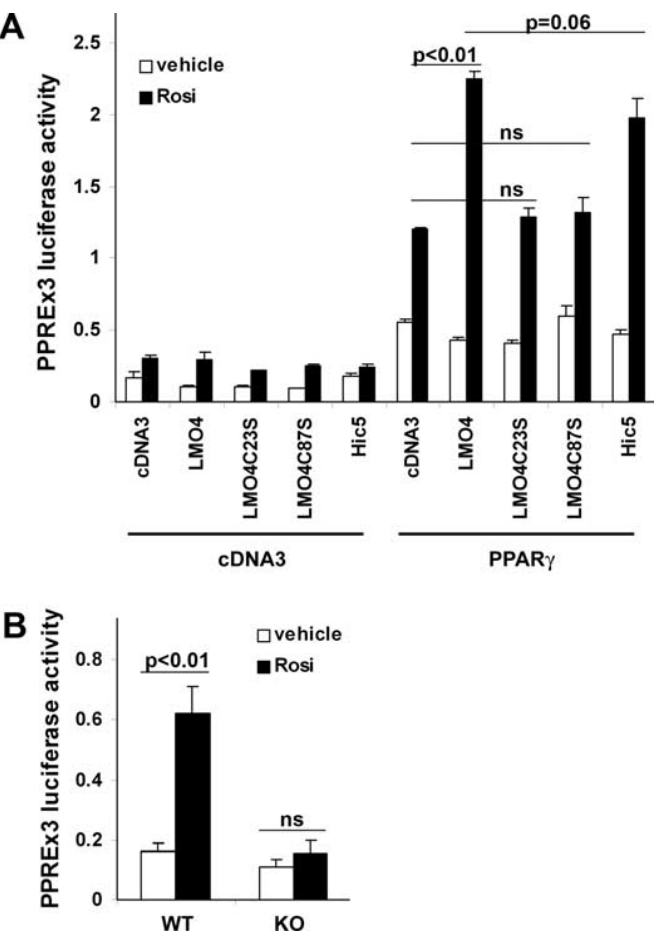

Figure 2. A, LM04 augments the activity of a PPAR $\gamma$-responsive promoter (PPREX3) in the presence of PPAR $\gamma$ and agonist rosiglitazone in F11 cells. PPAR $y$ expression vector was cotransfected with expression vectors for myc-tagged wild-type LM04, mutant LMO4 (C23S or C87S), or Hic5 together with the luciferase reporter of the PPREx3 promoter and the CMV $\beta$ galactosidase plasmid to normalize transfection efficiency. The CMV-dependent eukaryotic expression vector CDNA3 that was used to express LM04 and PPAR $\gamma$ was used as the negative control for transient transfections. Mutation of cysteines in the LIM1 or LIM2 domains of LM04 disrupts its coactivation function $(n=6)$. $\boldsymbol{B}$, The PPAR $\gamma$-responsive promoter is not activated by rosiglitazone in LMO4-null cortical neurons $(n=3)$. Data presented are mean $\pm \mathrm{SE}$.

revealed Cre recombinase expression in CaMKII $\alpha$ Cre/LMO4loxP brain at $\mathrm{P} 11$ but not at $\mathrm{P} 3$.

MCAO model. All procedures followed the guidelines of the Canadian Council for Animal Care and were approved by the Animal Care Committee of the University of Ottawa. Transient MCAO was performed in 7- to 8-week-old anesthetized male mice. Body temperature was monitored by a rectal probe and maintained at $37.0 \pm 0.6^{\circ} \mathrm{C}$ using a heated pad (Harvard Apparatus). Left MCAO was induced using the intraluminal suture method (Longa et al., 1989). The 0.2-mm-diameter (4-0) nylon monofilament coated with silicone remained in place for $60 \mathrm{~min}$, was withdrawn, and wounds were sutured. Blood flow was monitored by laser Doppler flowmeter (LDF100C; Biopac) using a flexible probe positioned at the surface of the dura exposed by a $2 \mathrm{~mm}$ burr hole in the left parietal bone to verify occlusion and ensure blood flow is restored to normal before returning the mice to their cages. Vehicle or rosiglitazone prepared as described previously (Luo et al., 2006) was administered intraperitoneally $(6 \mathrm{mg} / \mathrm{kg})$ immediately after reperfusion and again $48 \mathrm{~h}$ later.

Baseline physiological parameters were measured in two separate groups of six CaMKIIaCre/LMO4loxP mice and six littermate control LMO4loxP mice. Blood was drawn before $\mathrm{MCAO}$ and immediately after filament withdrawal to measure arterial oxygen $\left(\mathrm{PaO}_{2}\right)$ and carbon dioxide $\left(\mathrm{PaCO}_{2}\right)$ and blood $\mathrm{pH}$ using an i-STAT analyzer. Heart rate and systolic and diastolic blood pressures were measured with a tail cuff manometer (BP-2000 Blood Pressure Analysis System; VisiTech System). Blood glucose was measured using Freestyle Blood Glucose Monitoring System (Abbott).

For histology, brains were fixed with $4 \%$ paraformaldehyde in PBS, frozen in $\mathrm{CO}_{2}$ gas, sectioned on a cryostat $(14 \mu \mathrm{m})$, and stained with cresyl violet or immunostained with primary antibody followed by HRP- 
conjugated tissue-appropriate secondary antibody and the DAB detection kit (Vector) as described by the manufacturer.

Measurement of infarct volume. The $2 \mathrm{~mm}$ fresh brain slices were stained with 2\% TTC solution (in saline) and postfixed with $4 \%$ paraformaldehyde. The infarct and hemisphere areas of each section were scanned and measured using AxioVision software (Zeiss). To calculate cerebral infarct volume, the influence of cerebral edema was excluded using the following correction formula: $\%$ cerebral edema $=([$ volume of infarcted hemisphere - volume of normal hemisphere]/volume of normal hemisphere $)^{*} 100$. The corrected infarct volume was calculated as follows: (actual measurement infarct volume $)^{*}[100 /(100+\%$ cerebral edema)]. The final relative infarct volume equals $100^{\star}$ (corrected infarct volume/volume of normal hemisphere ${ }^{\star} 2$ ). Paired $t$ test was used to compare infarct volumes and considered to be significant at $p<0.05$.

\section{Results}

LMO4 and PPAR $\gamma$ expression is

elevated after ischemic insult

Elevated LMO4 nuclear staining was detected by immunohistochemistry $4 \mathrm{~h}$ after MCAO in the cortex and striatum adjacent to the infarction (Fig. $1 A$ ). Dual immunofluorescence staining revealed that LMO4 and PPAR $\gamma$ are coexpressed in the same cortical neurons in the area surrounding the infarction (Fig. 1B). We then tested whether LMO4 expression responds to ischemic stress in cultured neuronal F11 cells. F11 cells derived from a fusion between embryonic day 13 rat dorsal root ganglion sensory neurons and mouse neuroblastoma (Platika et al., 1985) are easily cultured and express neuron specific markers, including microtubule-associated protein 2 in neurites (supplemental Fig. 1C, available at www. jneurosci.org as supplemental material). Similarly, after $2.5 \mathrm{~h}$ of OGD, LMO4 is rapidly upregulated $30 \mathrm{~min}$ after reperfusion and elevated levels are sustained up to $16 \mathrm{~h}$ (supplemental Fig. 1 $A, B$, available at www. jneurosci.org as supplemental material). PPAR $\gamma$ was also upregulated after OGD in F11 cells.

\section{LMO4 promotes PPAR $\boldsymbol{\gamma}$-dependent gene activation}

A previous study showed that Hic5 interacts with PPAR $\gamma$ in the intestinal epithelium and promotes ligand-dependent gene activation through its LIM domains (Drori et al., 2005). Here, we determined whether LIM domain-only protein 4 that is highly expressed in the developing nervous system affects PPAR $\gamma$ signaling in F11 neuronal cells (Fig. $2 A)$. In F11 cells, the PPAR $\gamma$-responsive PPREx3-luciferase reporter (containing three tandem DR1 elements) was activated by rosiglitazone in the presence of PPAR $\gamma$ expression vector. Over-
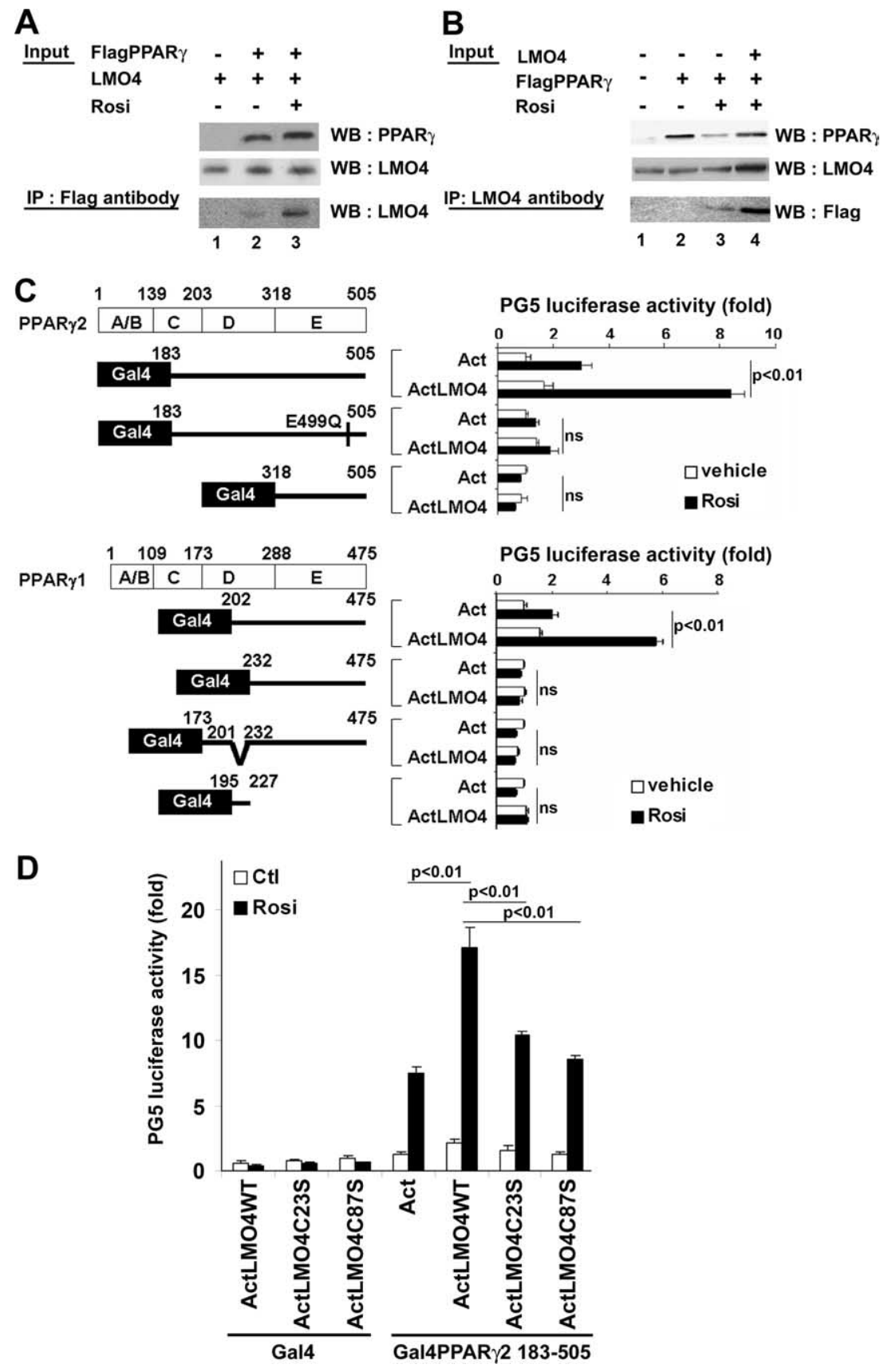

Figure 3. Physical and functional interaction of LM04 with PPAR $\gamma$. Nuclear extracts from F11 cells transfected with LM04 with or without Flag-PPAR $\gamma$ were immunoprecipitated with anti-Flag $(\boldsymbol{A})$ or anti-LM04 antibody $(\boldsymbol{B})$ and analyzed by Western blot using LM04, PPAR $\gamma$, and Flag antibodies as indicated. Rosiglitazone (10 $\mu \mathrm{M})$ increases LM04 binding to PPAR $\gamma$. IP, Immunoprecipitation; WB, Western blot. C, Mammalian two-hybrid assays in F11 cells revealed that the hinge region of PPAR $\gamma$ (domain D) is necessary for LMO4 to interact with ligand-binding domain of PPAR $\gamma$ (domains $D$ and E). Rosiglitazone augments this interaction $(n=6)$. CMV $\beta$-galactosidase plasmid was cotransfected with pG5luciferase reporter and pAct and GAL 4 expression vectors that carry LMO4 and PPAR $\gamma$ constructs, as indicated. Transfection efficiency was first normalized to the $\beta$-galactosidase activity and luciferase activity of the pG5 reporter was expressed as a fold of the activity in the presence of GAL4-PPAR $\gamma 2$ 183-505 vector cotransfected with the empty Act vector. To be noted, PPAR $\gamma 2$ shares identical sequences as PPAR $\gamma 1$ but has an additional 30 aa at the N-terminal end as a result of alternative splicing. $D$, Both LIM domains of LMO4 are required for PPAR $\gamma$ interaction. Mutation of either cysteine 23 in the first LIM domain or cysteine 87 in the second LIM domain to a serine residue interfered with LM04 interaction with PPAR $\gamma$. Transfection was performed as in C. Cells were treated with $10 \mu \mathrm{m}$ rosiglitazone for $8 \mathrm{~h}$ before harvesting for luciferase assay. Data are mean $\pm \operatorname{SE}(n=6)$.

expression of LMO4 together with PPAR $\gamma$ activated the PPREx3 luciferase reporter to the same extent as did the other LIM domain PPAR $\gamma$ cofactor Hic5. LMO4 mutant proteins that disrupt each of the LIM domains (C23S, C87S) and disrupt PPAR $\gamma$ in- 

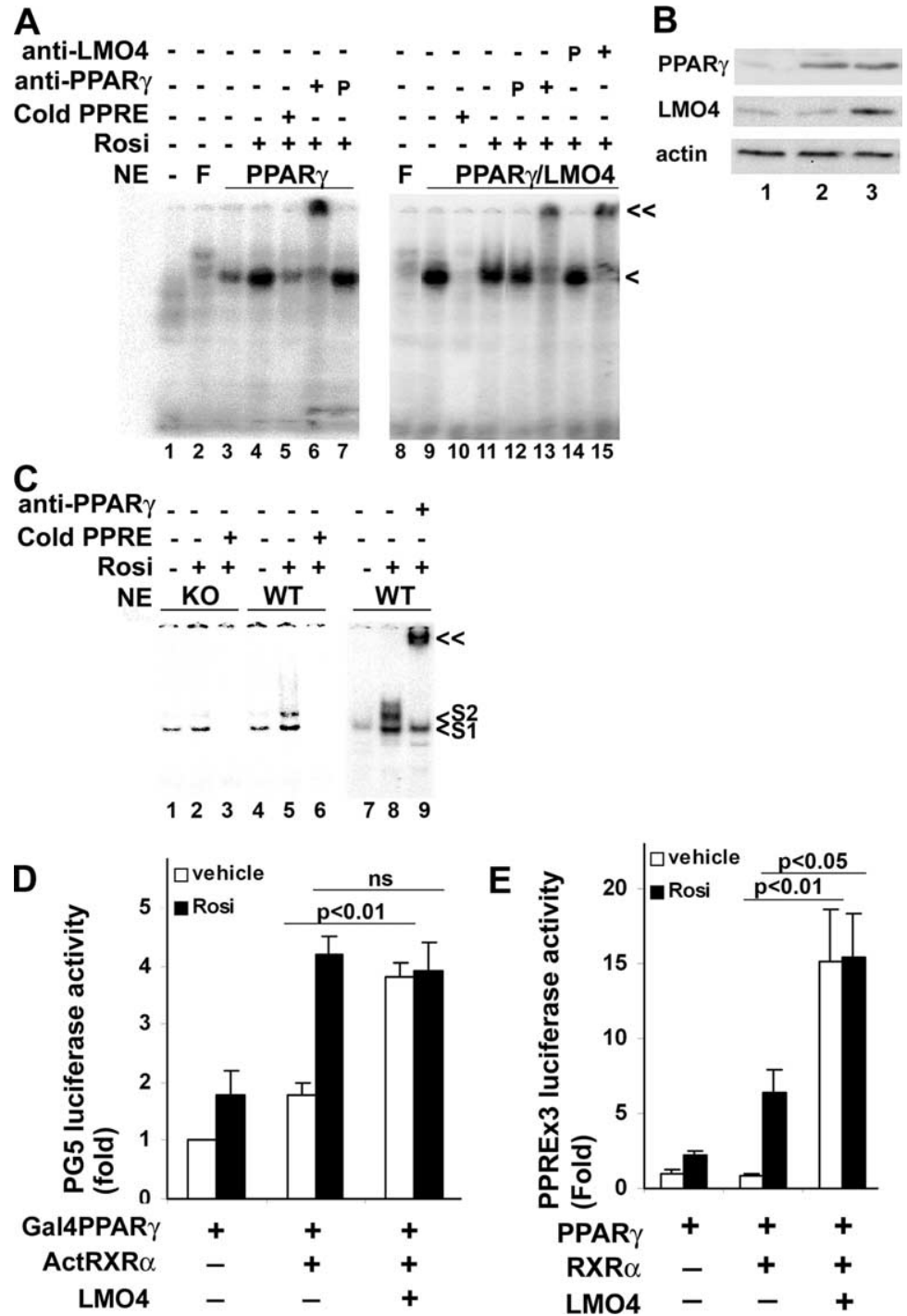

Figure 4. LMO4 augments PPAR $\gamma$ DNA binding. A, Electrophoretic mobility shift assay using nuclear extracts from F11 cells transfected with PPAR $\gamma$ alone (lanes 3-7) or together with LM04 (lanes 9-15). Rosiglitazone increases PPAR $\gamma$ DNA binding (compare lanes 4, 3). Overexpression of LM04 augments PPAR $\gamma$ DNA binding (lane 9), even without rosiglitazone. Antibodies to PPAR $\gamma$ (lanes 6, 13) and LMO4 (lane 15) supershifted these proteins (SS). $\boldsymbol{B}$. Western blot analysis revealed the levels of PPAR $\gamma$ and LM04 in nuclear protein extracts used in $\boldsymbol{A}$. Lanes 1,2 , and 3 in $\boldsymbol{B}$ correspond to lanes 2 and $8,3-7$, and $9-15$ in $\boldsymbol{A}$, respectively. C, Mammalian two-hybrid assay shows LM04 overexpression enhances PPAR $\gamma 2$ interaction with RXR $\alpha$, even without rosiglitazone $(n=6)$. CMV $\beta$-galactosidase plasmid was cotransfected with pG5luciferase reporter and pAct and GAL 4 expression vectors that carry RXR $\alpha$ and PPAR $\gamma$ (PPAR $\gamma 2$ 183-505) constructs, as indicated. Transfection efficiency was first normalized to the $\beta$-galactosidase activity and luciferase activity of the pG5 reporter was expressed as a fold of the activity in the presence of GAL4-PPAR $\gamma$ vector cotransfected with the empty pAct vector under vehicle-treated conditions. D, LM04 augments PPAR $\gamma /$ RXR $\alpha$ interaction at a PPAR $\gamma$-responsive promoter in a manner that is independent of rosiglitazone $(n=6)$. CMV $\beta$-galactosidase plasmid was cotransfected with PPREx3 luciferase reporter and CDNA3 expression vectors that carry RXR $\alpha$ and PPAR $\gamma$ (PPAR $\gamma 2$ 183-505) constructs, as indicated. Transfection efficiency was first normalized to the $\beta$-galactosidase activity and luciferase activity of the PPREX3 reporter was expressed as a fold of the activity in the presence of PPAR $\gamma$ expression vector cotransfected with the empty CDNA3 vector under vehicle-treated conditions. Data presented are mean \pm SE. $E$, Electrophoretic mobility shift assay using nuclear extracts from brain of P11 CaMKII $\alpha$ Cre/LM04loxP or littermate control LM04 loxP mice. Rosiglitazone increases PPAR $\gamma$ DNA binding in LM04loxP but not in CaMKII $\alpha$ Cre/LM04loxP mice (compare lanes 2, 3, and 5,6). The specificity of PPAR $\gamma$-binding activity was confirmed by supershift with PPAR $\gamma$ antibody (SS, lane 3) and by competition of binding with unlabeled PPRE oligonucleotides (lanes 7,8).
LMO4-null cortical neurons (Fig. 2B). These results also show that endogenous Hic5 is not sufficient to compensate for the absence of LMO4 and that LMO4 is required to activate a $\operatorname{PPAR} \gamma$-responsive promoter in neurons.

\section{LMO4 interacts with PPAR $\gamma$}

Using whole-cell extracts from cultured F11 neuronal cells transfected with LMO4 and Flag-epitope tagged PPAR $\gamma$ expression vectors, coimmunoprecipitation with a Flag-antibody showed that LMO4 physically interacts with PPAR $\gamma$ (Fig. 3A, lane 2). Moreover, treating F11 cells with the $\operatorname{PPAR} \gamma$ agonist rosiglitazone increased the amount of LMO4 immunoprecipitated with PPAR $\gamma$ (Fig. 3A, lane 3). Similarly, Flag-epitope tagged PPAR $\gamma$ could be immunoprecipitated with endogenous and overexpressed mycLMO4 using a peptidespecific rabbit LMO4 antibody (Fig. $3 B$, lanes 3,4).

Mammalian two-hybrid assays using various truncations and deletions of $\operatorname{PPAR} \gamma$ further characterized the interaction of LMO4 with PPAR $\gamma$ (Fig. 3C). Deletion of amino acids 201-232 of PPAR $\gamma 1$ that contain the hinge helixl region (amino acids 206-224) prevented LMO4 binding. However, amino acids 201-232 at the hinge region of PPAR $\gamma$ alone were not sufficient to interact with LMO4. Disruption of the zinc fingers in the first LIM domain (C23S) or in the second LIM domain (C87S) interfered with LMO4 interaction with PPAR $\gamma$ (Fig. 3D). Thus, both LIM domains are required for functional interaction.

Consistent with our coimmunoprecipitation result, rosiglitazone increased LMO4 interaction with PPAR $\gamma$. Studies of the crystal structure of PPAR $\gamma$ indicate that ligand binding leads to conformational changes in PPAR $\gamma$ to recruit coactivators (Nolte et al., 1998). A mutation of $\operatorname{PPAR} \gamma(\mathrm{E} 499 \mathrm{Q})$ in the ligand binding domain that retains its ability to bind to $\operatorname{PPAR} \gamma$ ligand but fails to recruit transcription cofactors (Hauser et al., 2000) did not interact with LMO4 in the twohybrid assay. Thus, a ligand-dependent conformational change may recruit LMO4 to PPAR $\gamma$ and failure to recruit LMO4 would impair PPAR $\gamma$-dependent gene activation. teraction also abrogated the effect of LMO4 coactivation, suggesting that both LIM domains of LMO4 are required for PPAR $\gamma$-dependent gene activation in F11 cells.

The response of the PPREx 3 luciferase reporter was also measured in primary cortical neuron cultures. Rosiglitazone activated the PPREx3 luciferase reporter in wild-type but not in

\section{LMO4 augments PPAR $\gamma$ DNA binding}

To test how LMO4 affects PPAR $\gamma$ DNA binding, F11 neuronal cells were transiently transfected with Flag-tagged PPAR $\gamma$ alone or together with LMO4 expression plasmids. Nuclear extracts prepared from transfected cells were used in gel mobility shift assays using an oligonucleotide containing the PPAR $\gamma$ consensus 
DR1 sequence (Fig. 4A). PPAR $\gamma$ binding to the probe was increased by rosiglitazone (Fig. 4A, compare lanes 3, 4). Surprisingly, overexpression of LMO4 was sufficient to increase PPAR $\gamma$ DNA binding even in the absence of rosiglitazone (Fig. $4 A$, compare lanes 3, 9), and rosiglitazone did not further increase PPAR $\gamma$ DNA binding (Fig. $4 A$, compare lanes 9,11 ). Western blot analysis showed that similar levels of expressed Flag-PPAR $\gamma$ were detected in the nuclear extracts of F11 cells with and without LMO4 overexpression (Fig. 4B, compare lanes 2, 3), indicating that increased DNA binding by PPAR $\gamma$ likely results from its interaction with LMO4. Supershift was observed with both anti-PPAR $\gamma$ and anti-LMO4 antibodies, demonstrating the presence of LMO4 in the PPAR $\gamma /$ DNA complex (Fig. 4A, lanes 6, 13, 15).

Dimerization of RXR $\alpha$ with PPAR $\gamma$ increases PPAR $\gamma$ binding to the DR1 consensus sequence (Okuno et al., 2001), an essential step to activate PPAR $\gamma$ dependent gene expression. We did not observe a direct interaction between LMO4 and $\operatorname{RXR} \alpha$ in a two-hybrid assay (data not shown). However, overexpression of LMO4 increased the interaction between PPAR $\gamma$ and $\operatorname{RXR} \alpha$ under basal conditions and no additional increase in interaction was observed when F11 cells were treated with rosiglitazone (Fig. 4C). Similarly, addition of LMO4 further activated the PPREx3 promoter when cotransfected with $\operatorname{RXR} \alpha$ and $\operatorname{PPAR} \gamma$, but this effect was not further increased by addition of rosiglitazone (Fig. $4 D$ ). Together, these results suggest that LMO4 can increase the sensitivity of PPAR $\gamma$ signaling by modulating recruitment of $\operatorname{RXR} \alpha$ and DNA binding of PPAR $\gamma$.

\section{PPAR $\gamma$ requires LMO4 to protect} cultured cortical neurons from ischemic injury

To evaluate the requirement of LMO4 in PPAR $\gamma$-dependent neuroprotection, primary cortical neurons from wild-type and LMO4-null (KO) mouse embryos were cultured under conditions that mimic ischemic insult. As we reported previously, cultured cortical neurons from LMO4-null mouse embryos do not differ from those of wild-type mice in terms of their viability under optimal culture conditions (Chen et al., 2007b). In addition, we did not observe a different staining pattern for the mitochondrial marker hsp60 in LMO4-null and wild-type neurons (supplemental Fig. $1 D$, available at www.jneurosci.org as supplemental material), suggesting similar mitochondrial biogenesis (Martínez-Diez et al., 2006). However, LMO4-null neurons were more sensitive to NMDA and OGDinduced cell death than wild-type neurons (Fig. 5A) $(p<0.05)$, whereas $\mathrm{KCN}$ was equally potent at killing wild-type and LMO4null neurons. Moreover, rosiglitazone rescued wild-type but not LMO4-null cortical neurons from all three insults. The PPAR $\gamma$ antagonist GW9662 blocked rosiglitazone-mediated protection of wild-type neurons, demonstrating that this effect occurs through PPAR $\gamma$. Importantly, restoration of LMO4 expression in cultured LMO4-null cortical neurons by transient transfection with an LMO4-GFP expression vector restored the protective effect of PPAR $\gamma$ signaling after KCN treatment. In Figure $5 B$, $\mathrm{LMO}_{4}{ }^{+} \mathrm{GFP}^{+}$neurons show intact nuclei, whereas untransfected or $\mathrm{GFP}^{+}$vector transfected neurons show picnotic dying nuclei. The effect was quantified in Figure $5 C$. Similar results were obtained after OGD (Fig. 5D). These results support the notion that LMO4 is essential for PPAR $\gamma$ signaling to rescue neurons from ischemic injury.

LMO4 neuron-deficient mice are more susceptible to focal brain ischemia

To test whether LMO4 protects from ischemic injury in vivo, we generated transgenic mice with selective postnatal ablation of 


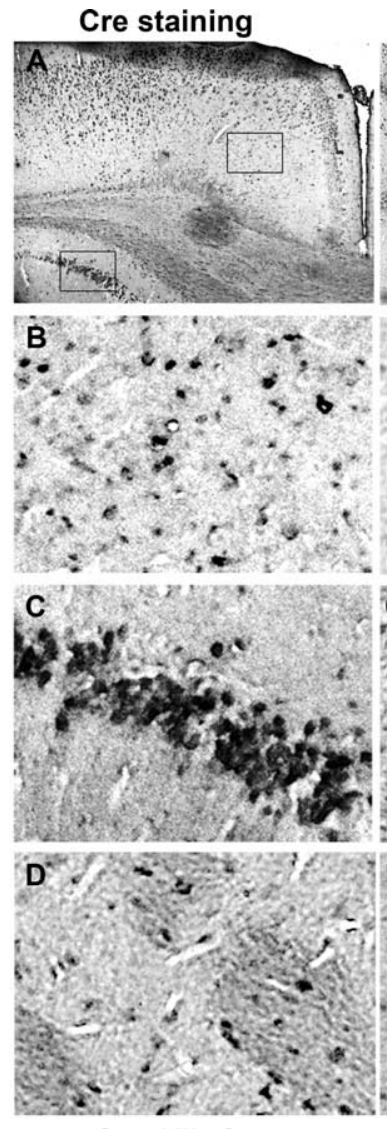

CamKIl $\alpha$ Cre

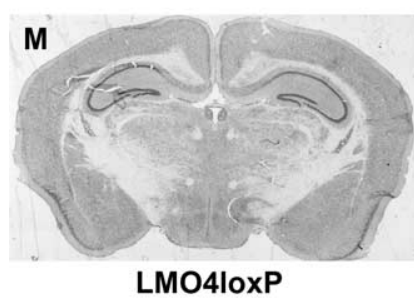

N

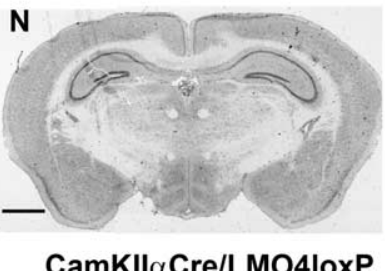

CamKIl $\alpha$ Cre/LMO4loxP
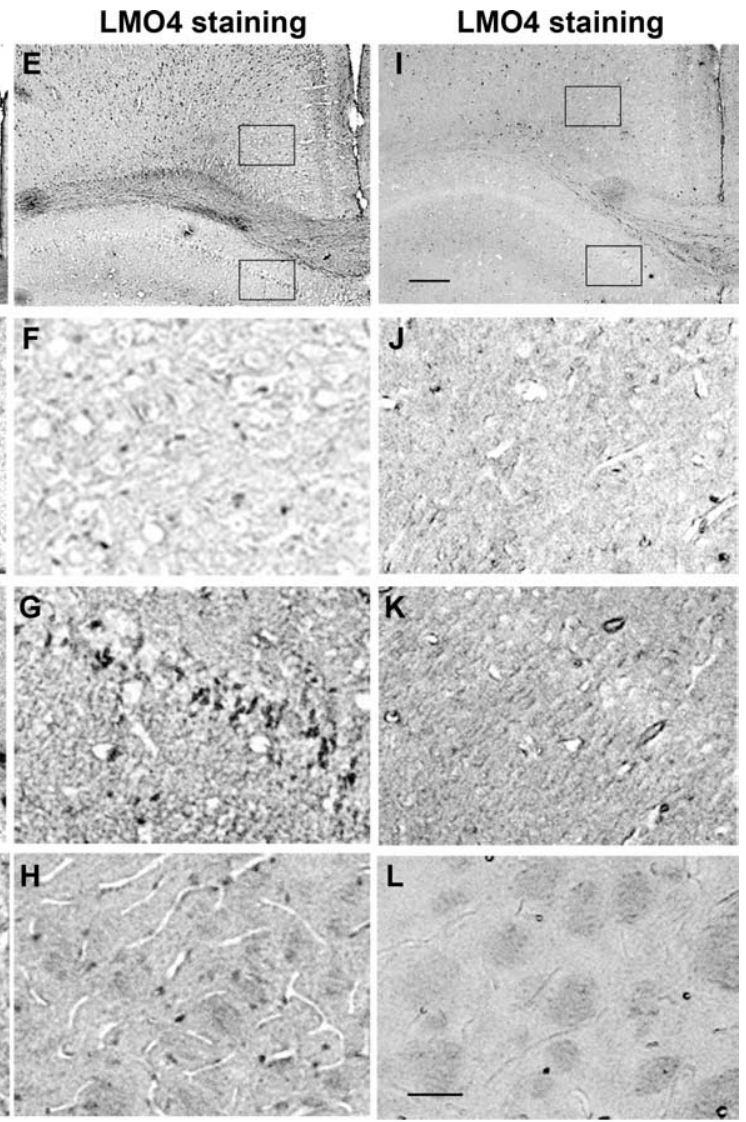

CamKIll Cre/LMO4loxP

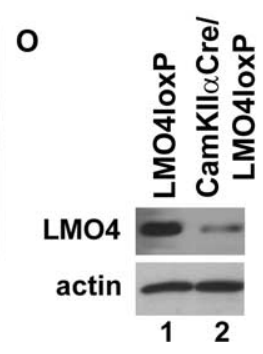

Figure 6. CaMKII $\alpha$ Cre/LM04loxP mice show reduced levels of LMO4 in the brain. Correlation between the pattern of Cre recombinase expression and reduced expression of LMO4 was revealed by immunohistochemistry using $(r e(A-D)$ antibody in 7-week-old CaMKIl $\alpha$ Cre mice and LM04 antibody in control LM04loxP mice $(\boldsymbol{E}-\boldsymbol{H})$ or in CaMKIl $\alpha$ Cre/LM04loxP mice $(\boldsymbol{I}-\boldsymbol{L})$. Enlarged boxed insets at the cortex and hippocampus are shown in $\boldsymbol{B}, \boldsymbol{F}, \boldsymbol{J}$, and $\boldsymbol{C}, \boldsymbol{G}, \boldsymbol{K}$, respectively. $\boldsymbol{D}, \boldsymbol{H}$, and $\boldsymbol{L}$ show similar magnification of the striatum. Cresyl violet staining of brain sections showed no overt difference between morphology of the CaMKII $\alpha$ Cre/LM04loxP $(\boldsymbol{N})$ and littermate control LM04loxP mice $(\boldsymbol{M})$. 0, Western blot showed a 90\% lower level of LM04 in CaMKII $\alpha$ Cre/LM04loxP brain compared with littermate LM04loxP mice. Scale bars: $\boldsymbol{A}, \boldsymbol{E}, \boldsymbol{I}, 200 \mu \mathrm{m} ; \boldsymbol{B}-\boldsymbol{D}, \boldsymbol{F}-\boldsymbol{H}, \boldsymbol{J}-\boldsymbol{L}, 20 \mu \mathrm{m} ; \boldsymbol{M}$, $N, 1 \mathrm{~mm}$.

LMO4 in neurons of the forebrain (CaMKII $\alpha$ Cre/LMO4loxP). Mice expressing Cre-recombinase under the neuron-specific CaMKII $\alpha$ promoter (Casanova et al., 2001) were crossed with LMO4loxP mice carrying loxP sites flanking the LMO4 gene (Hahm et al., 2004) to ablate LMO4 in neurons of the forebrain after the first postnatal week. Outwardly, CaMKII $\alpha$ Cre/ LMO4loxP mice appear normal. Immunohistochemical examination confirmed the expression of Cre-recombinase and the correlated reduction of LMO4 expression (Fig. 6; supplemental Figs. 2, 3, available at www.jneurosci.org as supplemental material). However, cresyl violet staining of brain sections did not reveal structural differences between CaMKII $\alpha$ Cre/LMO4loxP and littermate control LMO4loxP mice (Fig. $6 M, N$ ). Western blot analysis showed a $90 \%$ reduction in the levels of LMO4 in the forebrain (Fig. $60)$.

LMO4loxP littermate control and CaMKII $\alpha$ Cre/LMO4loxP mice were subjected to $1 \mathrm{~h}$ of transient focal ischemia by occluding the middle cerebral artery. Laser Doppler flowmetry (Fig. 7B) revealed no difference in blood flow before and after MCAO that would suggest a functional deficit. However, TTC staining revealed a larger infarction in CaMKII $\alpha \mathrm{Cre} /$ LMO4loxP mice compared with littermate controls $24 \mathrm{~h}$ after reperfusion (Fig. 7C). After $72 \mathrm{~h}$ (D3 vehicle), the difference in infarction volumes was still observed, but did not reach significance $(p=0.08)$. Importantly, rosiglitazone administered immediately after reperfusion and again $48 \mathrm{~h}$ later significantly reduced infarction volumes in control LMO4loxP mice, but not in CaMKII $\alpha$ Cre/LMO4loxP mice. No significant difference in measured physiological parameters was detected before or after MCAO between LMO4loxP and CaMKII $\alpha$ Cre/LMO4loxP mice (Table 1). However, PPAR $\gamma$ activity (protein-DNA binding) was significantly reduced in the brain of CaMKII $\alpha$ Cre/LMO4loxP mice compared with littermate control LMO4loxP mice (Fig. $4 E$ ). Together, these results suggest that loss of LMO4 in neurons increases susceptibility to ischemic injury and that LMO4 is essential for $\operatorname{PPAR} \gamma$-dependent neuroprotection in vivo.

\section{Neuron-specific ablation of LMO4 impairs PPAR $\gamma$ and PGC1 $\alpha$ upregulation after ischemia} CaMKII $\alpha$ Cre/LMO4loxP mice subjected to MCAO show an impaired response to rosiglitazone. This could be attributable to the absence of LMO4 as an essential cofactor of PPAR $\gamma$. In addition, reduced levels of PPAR $\gamma$ and other cofactors could also contribute to the impaired response. Elevated levels of PPAR $\gamma$ and PGC1 $\alpha$ were detected by immunohistochemistry in the cerebral cortex in the area near the infarction in LMO4loxP but not in CaMKII $\alpha$ Cre/LMO4loxP mice (Fig. 8). This result was confirmed by Western blot analysis of nuclear protein extracts prepared from brain tissue dissected near the infarction (Fig. $8 I$, lanes 2, 4; supplemental Fig. $4 A$, available at www.jneurosci.org as supplemental material).

\section{LMO4 mediates PPAR $\gamma$-dependent SOD2 upregulation} in neurons

$\operatorname{PPAR} \gamma$ activates the expression of the antioxidant gene SOD2 that scavenges free radicals and reduces oxidative stress (Ding et al., 2007). Western blot analysis showed that NMDA or OGD/ reperfusion increased the levels of SOD2 in wild-type but not in LMO4-null cortical neurons (Fig. 9A). This was correlated with 

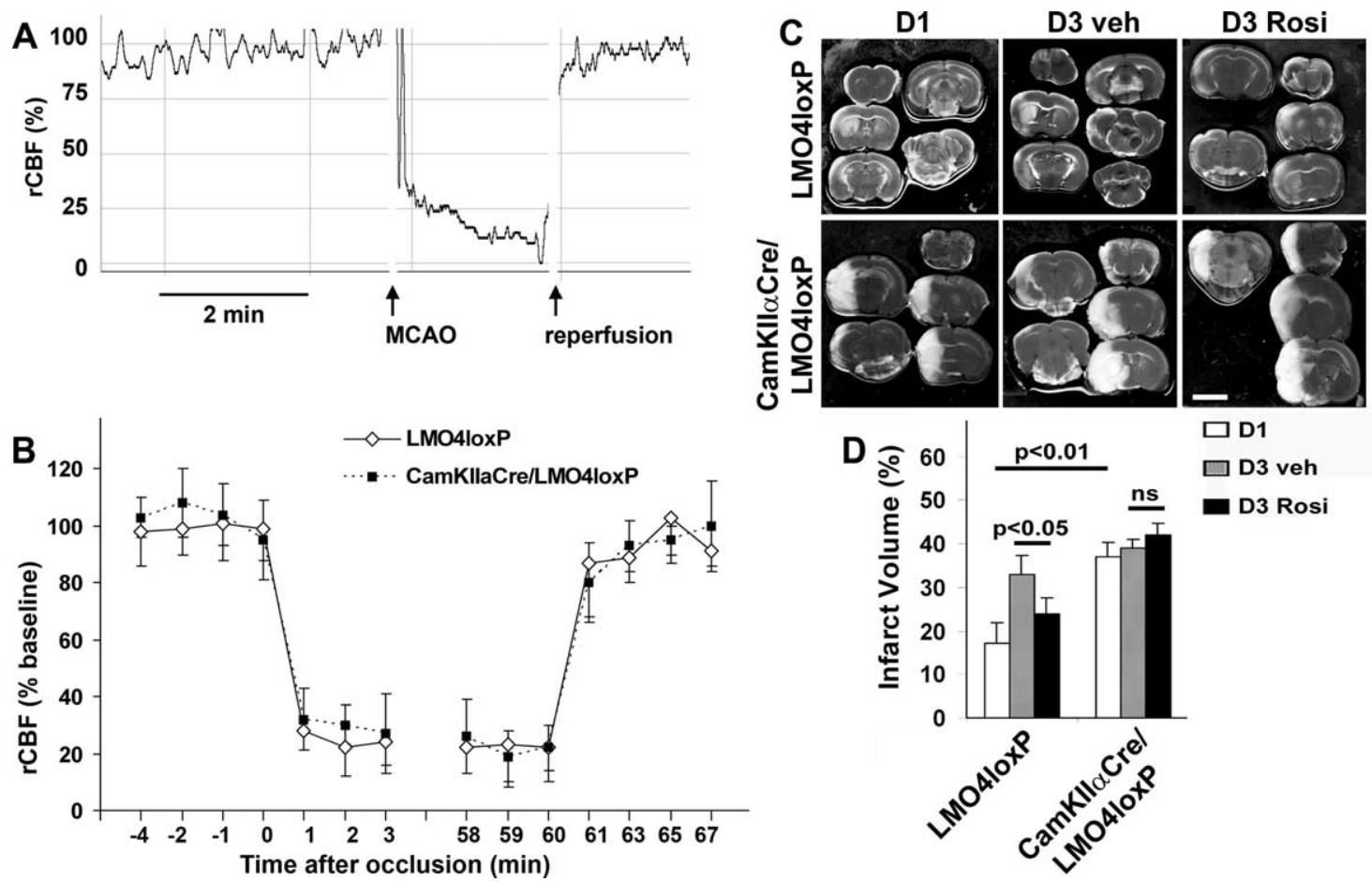

Figure 7. LMO4 neuron-deficient CaMKII $\alpha$ Cre/LM04loxP mice are more susceptible to focal ischemia. $A$, A representative tracing of the relative cortical blood flow (rCBF) as a percentage of baseline, measured across the cranial window by laser Doppler flowmetry before, during, and after $1 \mathrm{~h}$ occlusion of the middle cerebral artery. $\boldsymbol{B}$, No significant difference of rBCF between the control LM04loxP and CaMKII $\alpha$ Cre/LM04loxP mice was seen either before or after MCA0. All measurements of CBF were normalized to averaged baseline values for control LM04loxP mice before MCA0. Representative sections stained by TTC are shown in C and infarction volumes are quantified in $D$ after $24 \mathrm{~h}$ (D1; $n=8)$ or $72 \mathrm{~h}$ treated with vehicle (D3 veh; $n=5)$ or rosiglitazone (D3 Rosi; $n=$ 6). The difference between littermate control LM04IoxP and CaMKII $\alpha$ Cre/LM04loxP infarct volume at D1 is $p<0.01$. Rosiglitazone treatment reduced infarct volume in control LM04loxP ( $p<$ 0.05) but not in CaMKII $\alpha$ Cre/LM04loxP mice (ns, not significant). Data presented are mean \pm SE. Scale bar, $5 \mathrm{~mm}$.

Table 1. Physiological parameters before and after MCAO

\begin{tabular}{|c|c|c|}
\hline & LM04loxP & $\begin{array}{l}\text { CaMKII } \alpha \text { Cre/ } \\
\text { LM04loxP }\end{array}$ \\
\hline Weight (g) & $27.1 \pm 1.70$ & $28.2 \pm 0.64$ \\
\hline Systolic blood pressure $(\mathrm{mmHg})^{a}$ & $134.83 \pm 7.43$ & $141.64 \pm 5.76$ \\
\hline Diastolic blood pressure $(\mathrm{mmHg})^{a}$ & $100.65 \pm 8.51$ & $110.33 \pm 7.54$ \\
\hline Heart rate (beats $/ \mathrm{min}$ ) before $\mathrm{MCAO}^{a}$ & $606.89 \pm 27.43$ & $619.20 \pm 17.59$ \\
\hline Heart rate (beats/min) at reperfusion & $470.00 \pm 20.13$ & $446.67 \pm 13.74$ \\
\hline pH before MCAO & $7.37 \pm 0.07$ & $7.41 \pm 0.06$ \\
\hline pH at reperfusion & $7.41 \pm 0.03$ & $7.43 \pm 0.05$ \\
\hline $\mathrm{PaO}_{2}(\mathrm{mmHg})$ before $\mathrm{MCAO}$ & $124 \pm 18$ & $132 \pm 19$ \\
\hline $\mathrm{PaO}_{2}(\mathrm{mmHg})$ at reperfusion & $126 \pm 22$ & $120 \pm 16$ \\
\hline $\mathrm{PaCO}_{2}(\mathrm{mmHg})$ before $\mathrm{MCAO}$ & $41.2 \pm 4.3$ & $39.8 \pm 3.2$ \\
\hline $\mathrm{PaCO}_{2}(\mathrm{mmHg})$ at reperfusion & $40.5 \pm 5.7$ & $42.0 \pm 4.8$ \\
\hline Blood glucose before MCAO (mmol/L) & $5.83 \pm 0.32$ & $6.27 \pm 0.49$ \\
\hline
\end{tabular}

Values are means \pm SD of six mice per group.

${ }^{a} \mathrm{Blood}$ pressure and heart rate before MCAO were measured in restrained conscious mice.

increased LMO4, PPAR $\gamma$, and PGC1 $\alpha$ levels (supplemental Fig. $4 B$, available at www.jneurosci.org as supplemental material). Baseline levels of PGC1 $\alpha$ did not differ between LMO4 and wildtype neurons. Surprisingly, under basal conditions, PPAR $\gamma$ levels were higher in LMO4-null than in wild-type cortical neurons without higher baseline SOD2 expression, consistent with the idea that LMO4 is required for PPAR $\gamma$ to activate the SOD2 promoter (Fig. 9B). In addition, impaired upregulation of PPAR $\gamma$ and PGC1 $\alpha$ in LMO4-null neurons after ischemic stress would also limit SOD2 upregulation (Fig. 9A).

The mouse SOD2 promoter responds to PPAR $\gamma$ through a distal PPAR response element located between -985 and -935 (Ding et al., 2007). Rosiglitazone activated the long -985 , but not the short -935 SOD2 promoter in transiently transfected wildtype cortical neurons. In LMO4-null cortical neurons, the -985 SOD2 promoter was no more active than the -935 SOD2 promoter under basal conditions and was not activated by rosiglitazone (Fig. 9B). Thus, PPAR $\gamma$ requires LMO4 to elevate SOD2 levels in cortical neurons. Moreover, in situ measurement of oxygen consumption revealed no difference between wild-type and LMO4 cortical neurons in their bioenergetic response to NMDA (data not shown), indicating that lack of SOD2 and PPAR $\gamma$ upregulation in LMO4-null neurons likely did not reflect a generalized reduction in functional viability, particularly in ATPgenerating capacity, of these neurons.

To determine whether the inability of LMO4-null cortical neurons to be rescued from ischemic injury by PPAR $\gamma$ agonist reflects a defect in their PPAR $\gamma$ signaling pathway and the upregulation of the antioxidant gene SOD2 and not because of some other defect in these cells, we tested whether the SOD mimetic compound MnTBAP, a cell-permeant manganese porphyrin (Ding et al., 2007), could bypass defective PPAR $\gamma$ signaling. MnTBAP rescued LMO4-null cortical neurons from ischemic injury, just as in wild-type neurons (Fig. 9C), suggesting that there is no intrinsic difference in the apoptotic mechanisms in wild-type and LMO4-null neurons. Most wild-type and LMO4null neurons ( $>70 \%)$ rescued by MnTBAP continue to survive at least $3 \mathrm{~d}$ after NMDA treatment (Fig. 9D).

\section{Discussion}

There is currently considerable interest in determining whether $\operatorname{PPAR} \gamma$ agonists administered to patients at risk can reduce the incidence of stroke and/or can improve recovery from stroke (Culman et al., 2007). The success or failure of this approach will 

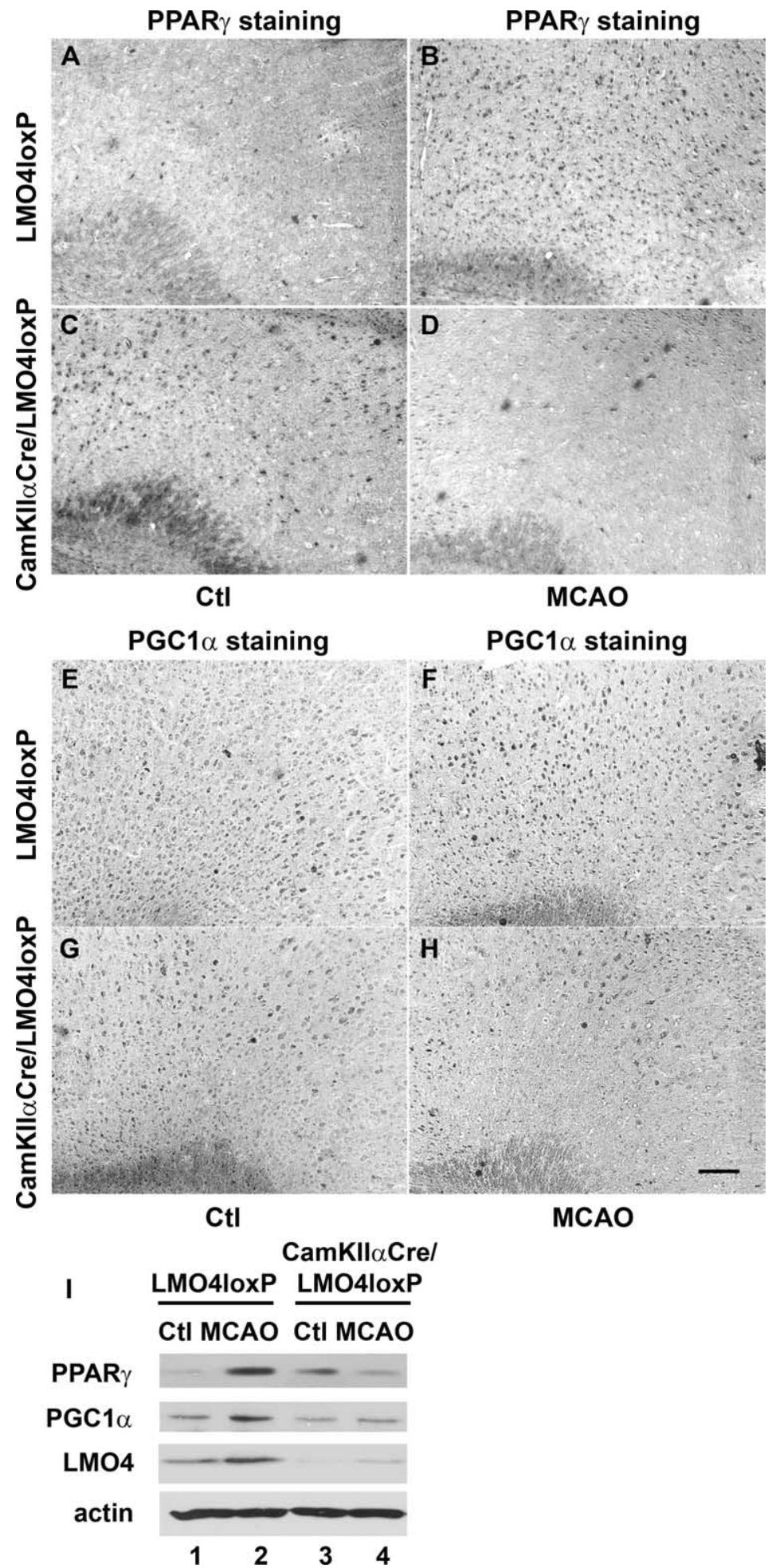

Figure 8. CaMKII $\alpha$ Cre/LM04loxP mice fail to upregulate PPAR $\gamma$ and PGC1 $\alpha$ expression after MCA0. Immunohistochemistry staining of PPAR $\gamma(\boldsymbol{A}-\boldsymbol{D})$ and PGC1 $\alpha(\boldsymbol{E}-\boldsymbol{H})$ was compared at the periinfarct cortex $16 \mathrm{~h}$ after $1 \mathrm{~h}$ of transient MCA0 in CaMKII $\alpha$ Cre/LM04loxP mice and littermate control LM04loxP mice. Ctl, Sham-operated control. Scale bar, $100 \mu \mathrm{m}$. I, Western blot analysis of PPAR $\gamma, \mathrm{PGC} 1 \alpha$, and LM04 expression in the nuclear subcellular fraction of brain extract from the periinfarct cortex (MCAO) of MCAO treated or sham-operated (Ctl) mice. Shown are representative results of $n=3$ per group. Quantified and normalized protein levels are shown in supplemental Figure $4 A$ (available at www.jneurosci.org as supplemental material).

be affected by the levels of PPAR $\gamma$ and its necessary cofactors. Here, we identified the small LIM domain-only protein LMO4 as an essential, hypoxia-induced cofactor of PPAR $\gamma$ that is required for $\operatorname{PPAR} \gamma$ to rescue neurons from ischemic injury. The PPAR $\gamma$ agonist rosiglitazone rescued nearly $80 \%$ of wildtype cortical neurons, an effect that was completely blocked by the PPAR $\gamma$-specific antagonist GW9662 (Fig. 5A). However, LMO4-null cortical neurons were refractory to the protective effect of rosiglitazone.

How is LMO4 required for PPAR $\gamma$ signaling? We found that LMO4 binds to PPAR $\gamma$ (Fig. 3) and promotes the interaction between RXR $\alpha$ and PPAR $\gamma$ (Fig. 4C). Dimerization of $\operatorname{RXR} \alpha$ with $\operatorname{PPAR} \gamma$ increases PPAR $\gamma$ binding to the DR1 consensus sequence of target genes (Okuno et al., 2001). When overexpressed in F11 neuronal cells, LMO4 augmented PPAR $\gamma$ DNA binding to a DR1 oligonucleotide to the same extent as can be achieved with exogenous ligand (Fig. 4A). Thus, a crucial role of LMO4 may be to increase the sensitivity of the PPAR $\gamma$ signaling pathway, especially when there are limited amounts of endogenous ligand. In addition, we found that ischemic injury upregulated the expression of PPAR $\gamma$ and the coactivator PGC1 $\alpha$ and that this upregulation also requires LMO4 (Figs. 8, 9). The PGC1 $\alpha$ promoter is regulated by cAMP response element-binding protein (CREB) (Herzig et al., 2001) and LMO4 may participate in CREB-dependent gene activation (Kashani et al., 2006). Therefore, in addition to a direct effect on PPAR $\gamma$ function, LMO4 can have an indirect effect on signaling by affecting the expression of PPAR $\gamma$ receptor and its cofactor PGC1 $\alpha$.

Our results show that LMO4 binds to $\operatorname{PPAR} \gamma$ in a ligand-dependent manner. Furthermore, we provide evidence that the helix 1 hinge region of PPAR $\gamma$ contributes to the PPAR $\gamma$-LMO4 interaction because deletion of the hinge helix 1 region disrupted LMO4 binding (Fig. 3C). The helix 1 of the hinge region of PPAR $\gamma$ is known to mediate protein-protein interaction with ERK5 (Hauser et al., 2000; Akaike et al., 2004) and protein kinase $\mathrm{C} \alpha(\mathrm{PKC} \alpha)$ (von Knethen et al., 2007). However, unlike in the case in which helix 1 is required and sufficient for interaction with the kinase ERK5 (Hauser et al., 2000), it was not sufficient to interact with PKC $\alpha$ (von Knethen et al., 2007) or with LMO4 (this study). Additional sequences in the AF2 ligand binding domain are also required because interaction was disrupted by a mutation at E499Q. Thus, a ligandinduced conformational change of $\operatorname{PPAR} \gamma$ may be involved in the recruitment of LMO4 to promote formation of an active transcription complex.

The activity and stability of PPAR $\gamma$ is tightly regulated by synthetic ligands like rosiglitazone. PPAR $\gamma$ is rapidly degraded on ligand binding (Hauser et al., 2000). Our observation of higher 


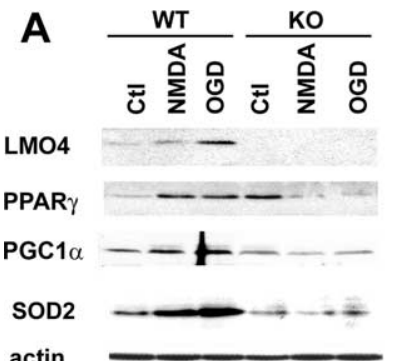

actin $\begin{array}{llllll}1 & 2 & 3 & 4 & 5 & 6\end{array}$
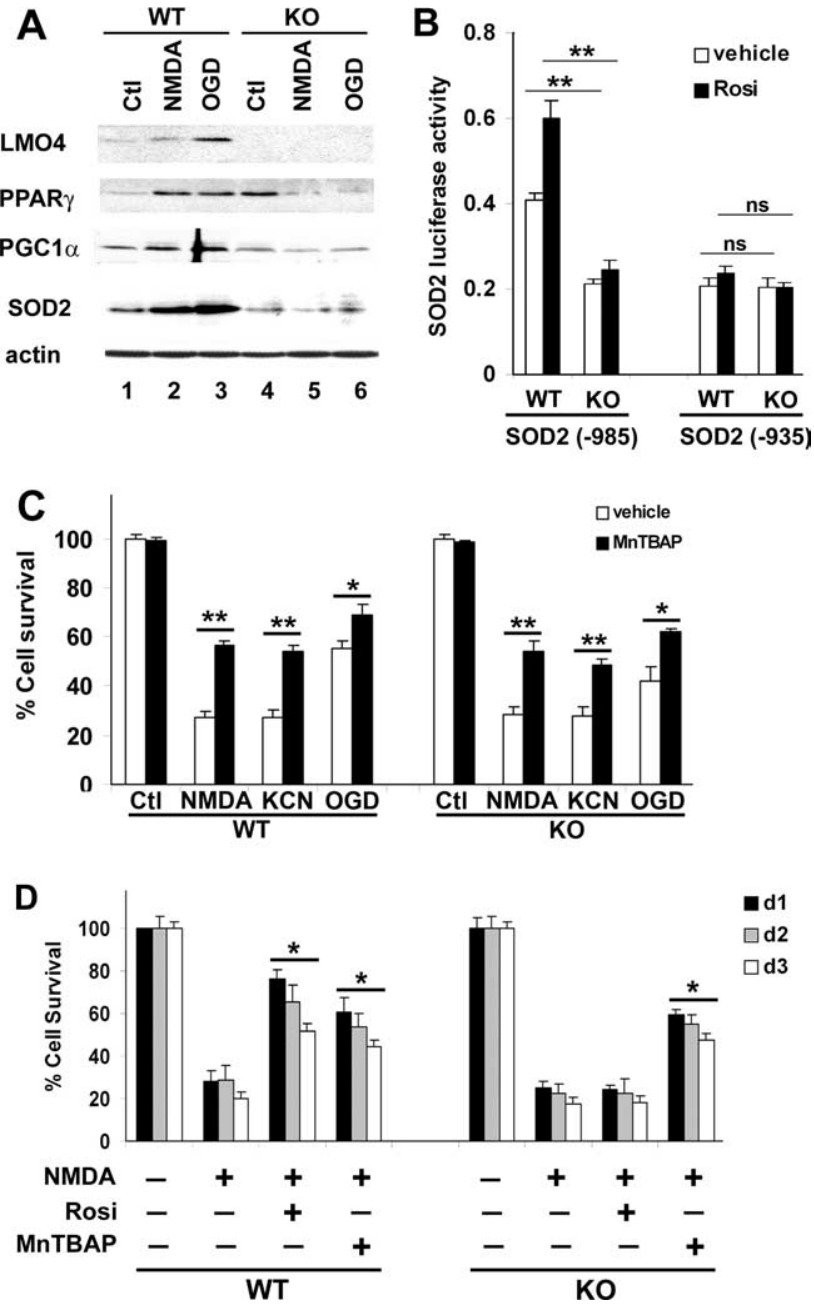

Figure 9. LMO4 controls SOD2 expression. $\boldsymbol{A}$, Western blot analysis reveals that SOD2 levels are induced after $12 \mathrm{~h}$ in wild-type but not in LM04-null cortical neurons in response to $3 \mathrm{~h}$ exposure to $100 \mu \mathrm{m}$ NMDA or to $6 \mathrm{~h}$ of $0 \mathrm{GD}$. Quantified and normalized protein levels are shown in supplemental Figure $4 B$ (available at www.jneurosci.org as supplemental material). $\boldsymbol{B}$, The SOD2-985 promoter is activated by rosiglitazone in wild-type but not LM04-null cortical neurons. The SOD2-935 promoter lacks the PPAR-response element (Ding et al., 2007). CMV $\beta$ galactosidase plasmid was cotransfected with SOD2 promoter luciferase reporters. Transfection efficiency was normalized to the $\beta$-galactosidase activity and corrected luciferase activity of the SOD2 reporters was shown $(n=4)$. C , The SOD-mimetic agent MnTBAP $(10 \mu \mathrm{m})$ added at the time of reperfusion rescues wild-type and LMO4-null cortical neurons from NMDA, KCN, and OGD-induced cell death. Note: In these experiments, neurons were treated with $100 \mu \mathrm{m}$ NMDA for $4 \mathrm{~h}(n=4)$. D, Cell survival after $4 \mathrm{~h}$ of $100 \mu \mathrm{m}$ NMDA treatment was compared 1, 2, and $3 \mathrm{~d}$ after treatment with $10 \mu \mathrm{m}$ rosiglitazone or $\operatorname{MnTBAP}(n=4)$. Data presented are mean $\pm \mathrm{SE}$. ${ }^{* *} p<0.001 ;{ }^{*} p<0.05$.

levels of PPAR $\gamma$ in LMO4-null cortical neurons under basal conditions was intriguing (Fig. 9A). Although LMO4-null mice might compensate for the lack of an essential cofactor by elevating PPAR $\gamma$ expression, these mice might also have less endogenous PPAR $\gamma$ ligand (PGJ2) and PPAR $\gamma$ would accumulate under basal conditions. Circulating levels of endogenous PPAR $\gamma$ ligand (PGJ2) are elevated after atherothrombotic stroke in patients and higher levels are correlated with a smaller infarction (Blanco et al., 2005). NMDA and OGD-induced ischemic stress caused increased levels of PPAR $\gamma$ in wild-type neurons but a loss of PPAR $\gamma$ in LMO4-null cortical neurons. Thus, LMO4 may stabilize PPAR $\gamma$ under stressful conditions that elevate endogenous PPAR $\gamma$ ligand levels.
What are the downstream targets of LMO4/PPAR $\gamma$ signaling required to protect neurons from ischemic injury? In cardiac myocytes, the SOD2 promoter is activated by a PPAR $\gamma$ responsive element located between -985 to -935 (Ding et al., 2007). This element also mediated the PPAR $\gamma$ response in wildtype but not LMO4-null cortical neurons (Fig. 9B). SOD2 is a critical mitochondrial antioxidant enzyme that defends against superoxide produced during ischemic insults. Increased SOD2 levels are correlated with increased neuronal tolerance to oxidative stress (Silva et al., 2005). SOD2 expression can be induced by NMDA in rat cortical neurons (Gonzalez-Zulueta et al., 1998).

NMDA and OGD both upregulated SOD2 levels in wild-type but not LMO4-null cortical neurons (Fig. 9A, compare lanes 2, 3, and 5,6$)$. Higher levels of SOD2 after OGD were correlated with higher survival of wild-type compared with LMO4-null cortical neurons (Fig. 9C). Consistent with this result, the mitochondrial superoxide indicator MitoSOX Red showed higher levels of superoxide in mitochondria of LMO4-null than in wild-type cortical neurons after OGD (supplemental Fig. 5, available at www. jneurosci.org as supplemental material). Similarly, elevated SOD2 levels (Fig. 9A) were also associated with improved survival after $3 \mathrm{~h}$ of NMDA treatment (Fig. $5 A$ ), but not with $4 \mathrm{~h}$ NMDA treatment (Fig. 9C,D), suggesting that SOD2 is not sufficient to rescue cortical neurons from prolonged NMDA insult. In our hands, NMDA treatment was more toxic to cortical neurons than OGD/reperfusion and upregulation of SOD2 in mitochondria may not be sufficient to curtail NMDA excitotoxicity.

Whereas SOD2 is a mitochondrial antioxidant, membranepermeable MnTBAP can scavenge free radicals both inside and outside the mitochondria. MnTBAP increased survival of both wild-type as well as LMO4-null cortical neurons from NMDA and OGD treatment, indicating that elevated reactive oxygen species contribute to cell death induced by both insults. It is worth noting that the initial effect of PPAR $\gamma$ signaling on promoting wild-type neuron survival (nearly $80 \%$ ) is greater than the effect of MnTBAP (up to 60\%) (Fig. 9D), suggesting that PPAR $\gamma$ signaling activates additional prosurvival mechanisms. For example, PPAR $\gamma$ signaling in neurons may also prevent inappropriate cell cycle reentry and apoptosis triggered during ischemic injury by restoring the levels of p27(Kip1), a cyclin-dependent kinase inhibitor that blocks cell cycle reentry (Zang et al., 2006).

It remains unclear how elevated LMO4 and PPAR $\gamma$ expression after NMDA or OGD is sufficient to activate SOD2 expression in wild-type neurons even without the addition of exogenous PPAR $\gamma$ ligand (Fig. 9A, lanes 2, 3). Neurons express prostaglandin $\mathrm{D}$ synthetase to produce their own endogenous PPAR $\gamma$ ligand (Mong et al., 2003). It is possible that ischemic insult elevates levels of endogenous PPAR $\gamma$ ligand in our cultured cortical neurons as occurs in patients with atherothrombotic stroke (Blanco et al., 2005) and accounts for elevated SOD2 expression.

Both PPAR $\gamma$ and LMO4 are highly expressed in embryonic neurons but are downregulated in adult neurons (Hermanson et al., 1999; Wada et al., 2006). Simultaneous upregulation of LMO4 with PPAR $\gamma$ in neurons after ischemia might be an important self-defense mechanism to survive ischemic injury. Brain ischemia triggers release of ATP into the extracellular space (Gourine et al., 2005). Our previous studies showed that elevated extracellular ATP prevents degradation of the labile LMO4 mRNA and augments LMO4 protein levels in neurons (Chen et al., 2007a,b). Whether similar mechanisms are responsible for increased PPAR $\gamma$ expression in neurons after ischemia remains to be determined. The increased levels of LMO4 after ischemia could be 
critical to limit ischemic damage after stroke. Polymorphisms in the promoter (Buckland et al., 2004) and 3'-untranslated region of LMO4 have been described in the single-nucleotide polymorphism database. Whether these polymorphisms account for genetic variability in LMO4 expression, the susceptibility to stroke injury, and influence the efficacy of PPAR $\gamma$ agonist therapy awaits additional study.

\section{References}

Akaike M, Che W, Marmarosh NL, Ohta S, Osawa M, Ding B, Berk BC, Yan C, Abe J (2004) The hinge-helix 1 region of peroxisome proliferatoractivated receptor gammal (PPARgammal) mediates interaction with extracellular signal-regulated kinase 5 and PPARgammal transcriptional activation: involvement in flow-induced PPARgamma activation in endothelial cells. Mol Cell Biol 24:8691-8704.

Blanco M, Moro MA, Dávalos A, Leira R, Castellanos M, Serena J, Vivancos J, Rodríguez-Yáñez M, Lizasoain I, Castillo J (2005) Increased plasma levels of 15-deoxyDelta prostaglandin J2 are associated with good outcome in acute atherothrombotic ischemic stroke. Stroke 36:1189-1194.

Boyle PJ (2007) Diabetes mellitus and macrovascular disease: mechanisms and mediators. Am J Med 120:S12-S17.

Buckland PR, Hoogendoorn B, Guy CA, Coleman SL, Smith SK, Buxbaum JD, Haroutunian V, O’Donovan MC (2004) A high proportion of polymorphisms in the promoters of brain expressed genes influences transcriptional activity. Biochim Biophys Acta 1690:238-249.

Casanova E, Fehsenfeld S, Mantamadiotis T, Lemberger T, Greiner E, Stewart AF, Schütz G (2001) A CamKIIalpha iCre BAC allows brain-specific gene inactivation. Genesis 31:37-42.

Chen HH, Yip JW, Stewart AF, Frank E (2002) Differential expression of a transcription regulatory factor, the LIM domain only 4 protein Lmo4, in muscle sensory neurons. Development 129:4879-4889.

Chen HH, Maeda T, Mullett SJ, Stewart AF (2004) Transcription cofactor Vgl-2 is required for skeletal muscle differentiation. Genesis 39:273-279.

Chen HH, Xu J, Safarpour F, Stewart AF (2007a) LMO4 mRNA stability is regulated by extracellular ATP in F11 cells. Biochem Biophys Res Commun 357:56-61.

Chen HH, Schock SC, Xu J, Safarpour F, Thompson CS, Stewart AF (2007b) Extracellular ATP-dependent upregulation of the transcription cofactor LMO4 promotes neuron survival from hypoxia. Exp Cell Res 313:3106-3116.

Culman J, Zhao Y, Gohlke P, Herdegen T (2007) PPAR-gamma: therapeutic target for ischemic stroke. Trends Pharmacol Sci 28:244-249.

Ding G, Fu M, Qin Q, Lewis W, Kim HW, Fukai T, Bacanamwo M, Chen YE, Schneider MD, Mangelsdorf DJ, Evans RM, Yang Q (2007) Cardiac peroxisome proliferator-activated receptor gamma is essential in protecting cardiomyocytes from oxidative damage. Cardiovasc Res 76:269-279.

Drori S, Girnun GD, Tou L, Szwaya JD, Mueller E, Xia K, Kia X, Shivdasani RA, Spiegelman BM (2005) Hic-5 regulates an epithelial program mediated by PPARgamma. Genes Dev 19:362-375.

Gonzalez-Zulueta M, Ensz LM, Mukhina G, Lebovitz RM, Zwacka RM, Engelhardt JF, Oberley LW, Dawson VL, Dawson TM (1998) Manganese superoxide dismutase protects nNOS neurons from NMDA and nitric oxide-mediated neurotoxicity. J Neurosci 18:2040-2055.

Gourine AV, Llaudet E, Dale N, Spyer KM (2005) Release of ATP in the ventral medulla during hypoxia in rats: role in hypoxic ventilatory response. J Neurosci 25:1211-1218.

Hahm K, Sum EY, Fujiwara Y, Lindeman GJ, Visvader JE, Orkin SH (2004) Defective neural tube closure and anteroposterior patterning in mice lacking the LIM protein LMO4 or its interacting partner Deaf-1. Mol Cell Biol 24:2074-2082.

Hauser S, Adelmant G, Sarraf P, Wright HM, Mueller E, Spiegelman BM (2000) Degradation of the peroxisome proliferator-activated receptor gamma is linked to ligand-dependent activation. J Biol Chem 275:18527-18533.

Hermanson O, Sugihara TM, Andersen B (1999) Expression of LMO-4 in the central nervous system of the embryonic and adult mouse. Cell Mol Biol (Noisy-le-grand) 45:677-686.

Herzig S, Long F, Jhala US, Hedrick S, Quinn R, Bauer A, Rudolph D, Schutz G, Yoon C, Puigserver P, Spiegelman B, Montminy M (2001) CREB regulates hepatic gluconeogenesis through the coactivator PGC-1. Nature 413:179-183.
Jia Y, Ransom RF, Shibanuma M, Liu C, Welsh MJ, Smoyer WE (2001) Identification and characterization of hic-5/ARA55 as an hsp27 binding protein. J Biol Chem 276:39911-39918.

Kashani AH, Qiu Z, Jurata L, Lee SK, Pfaff S, Goebbels S, Nave KA, Ghosh A (2006) Calcium activation of the LMO4 transcription complex and its role in the patterning of thalamocortical connections. J Neurosci 26:8398-8408.

Lee SK, Jurata LW, Nowak R, Lettieri K, Kenny DA, Pfaff SL, Gill GN (2005) The LIM domain-only protein LMO4 is required for neural tube closure. Mol Cell Neurosci 28:205-214.

Longa EZ, Weinstein PR, Carlson S, Cummins R (1989) Reversible middle cerebral artery occlusion without craniectomy in rats. Stroke 20:84-91.

Luo Y, Yin W, Signore AP, Zhang F, Hong Z, Wang S, Graham SH, Chen J (2006) Neuroprotection against focal ischemic brain injury by the peroxisome proliferator-activated receptor-gamma agonist rosiglitazone. J Neurochem 97:435-448.

Martínez-Diez M, Santamaría G, Ortega AD, Cuezva JM (2006) Biogenesis and dynamics of mitochondria during the cell cycle: significance of 3'UTRs. PLoS ONE 1:e107.

Mong JA, Devidze N, Frail DE, O’Connor LT, Samuel M, Choleris E, Ogawa S, Pfaff DW (2003) Estradiol differentially regulates lipocalin-type prostaglandin D synthase transcript levels in the rodent brain: evidence from high-density oligonucleotide arrays and in situ hybridization. Proc Natl Acad Sci U S A 100:318-323.

Nolte RT, Wisely GB, Westin S, Cobb JE, Lambert MH, Kurokawa R, Rosenfeld MG, Willson TM, Glass CK, Milburn MV (1998) Ligand binding and co-activator assembly of the peroxisome proliferator-activated receptor-gamma. Nature 395:137-143.

Okuno M, Arimoto E, Ikenobu Y, Nishihara T, Imagawa M (2001) Dual DNA-binding specificity of peroxisome-proliferator-activated receptor gamma controlled by heterodimer formation with retinoid $\mathrm{X}$ receptor alpha. Biochem J 353:193-198.

Ou XM, Jafar-Nejad H, Storring JM, Meng JH, Lemonde S, Albert PR (2000) Novel dual repressor elements for neuronal cell-specific transcription of the rat 5-HT1A receptor gene. J Biol Chem 275:8161-8168.

Platika D, Boulos MH, Baizer L, Fishman MC (1985) Neuronal traits of clonal cell lines derived by fusion of dorsal root ganglia neurons with neuroblastoma cells. Proc Natl Acad Sci U S A 82:3499-3503.

Puigserver P, Wu Z, Park CW, Graves R, Wright M, Spiegelman BM (1998) A cold-inducible coactivator of nuclear receptors linked to adaptive thermogenesis. Cell 92:829-839.

Raoul C, Estévez AG, Nishimune H, Cleveland DW, deLapeyrière O, Henderson CE, Haase G, Pettmann B (2002) Motoneuron death triggered by a specific pathway downstream of Fas potentiation by ALS-linked SOD1 mutations. Neuron 35:1067-1083.

Shibanuma M, Mashimo J, Kuroki T, Nose K (1994) Characterization of the TGF beta 1-inducible hic- 5 gene that encodes a putative novel zinc finger protein and its possible involvement in cellular senescence. J Biol Chem 269:26767-26774.

Silva JP, Shabalina IG, Dufour E, Petrovic N, Backlund EC, Hultenby K, Wibom R, Nedergaard J, Cannon B, Larsson NG (2005) SOD2 overexpression: enhanced mitochondrial tolerance but absence of effect on UCP activity. EMBO J 24:4061-4070.

Solaroglu I, Tsubokawa T, Cahill J, Zhang JH (2006) Anti-apoptotic effect of granulocyte-colony stimulating factor after focal cerebral ischemia in the rat. Neuroscience 143:965-974.

Tontonoz P, Hu E, Graves RA, Budavari AI, Spiegelman BM (1994) mPPAR gamma 2: tissue-specific regulator of an adipocyte enhancer. Genes Dev 8:1224-1234.

Tse E, Smith AJ, Hunt S, Lavenir I, Forster A, Warren AJ, Grutz G, Foroni L, Carlton MB, Colledge WH, Boehm T, Rabbitts TH (2004) Null mutation of the Lmo4 gene or a combined null mutation of the Lmo1/Lmo3 genes causes perinatal lethality, and Lmo4 controls neural tube development in mice. Mol Cell Biol 24:2063-2073.

Uryu S, Harada J, Hisamoto M, Oda T (2002) Troglitazone inhibits both post-glutamate neurotoxicity and low-potassium-induced apoptosis in cerebellar granule neurons. Brain Res 924:229-236.

Victor NA, Wanderi EW, Gamboa J, Zhao X, Aronowski J, Deininger K, Lust WD, Landreth GE, Sundararajan S (2006) Altered PPARgamma expression and activation after transient focal ischemia in rats. Eur J Neurosci 24:1653-1663.

von Knethen A, Soller M, Tzieply N, Weigert A, Johann AM, Jennewein C, 
Köhl R, Brüne B (2007) PPARgammal attenuates cytosol to membrane translocation of PKCalpha to desensitize monocytes/macrophages. J Cell Biol 176:681-694.

Wada K, Nakajima A, Katayama K, Kudo C, Shibuya A, Kubota N, Terauchi Y, Tachibana M, Miyoshi H, Kamisaki Y, Mayumi T, Kadowaki T, Blumberg RS (2006) Peroxisome proliferator-activated receptor gammamediated regulation of neural stem cell proliferation and differentiation. J Biol Chem 281:12673-12681.

Wilcox R, Bousser MG, Betteridge DJ, Schernthaner G, Pirags V, Kupfer S, Dormandy J (2007) Effects of pioglitazone in patients with type 2 diabetes with or without previous stroke: results from PROactive (PROspective pioglitAzone Clinical Trial In macroVascular Events 04). Stroke 38:865-873.
Zang C, Liu H, Waechter M, Eucker J, Bertz J, Possinger K, Koeffler HP, Elstner E (2006) Dual PPARalpha/gamma ligand TZD18 either alone or in combination with imatinib inhibits proliferation and induces apoptosis of human CML cell lines. Cell Cycle 5:2237-2243.

Zhang HL, Gu ZL, Savitz SI, Han F, Fukunaga K, Qin ZH (2008) Neuroprotective effects of prostaglandin $\mathrm{A}(1)$ in rat models of permanent focal cerebral ischemia are associated with nuclear factor-kappaB inhibition and peroxisome proliferator-activated receptor-gamma up-regulation. J Neurosci Res 86:1132-1141.

Zhao X, Ou Z, Grotta JC, Waxham N, Aronowski J (2006) Peroxisomeproliferator-activated receptor-gamma (PPARgamma) activation protects neurons from NMDA excitotoxicity. Brain Res 1073-1074: $460-469$. 